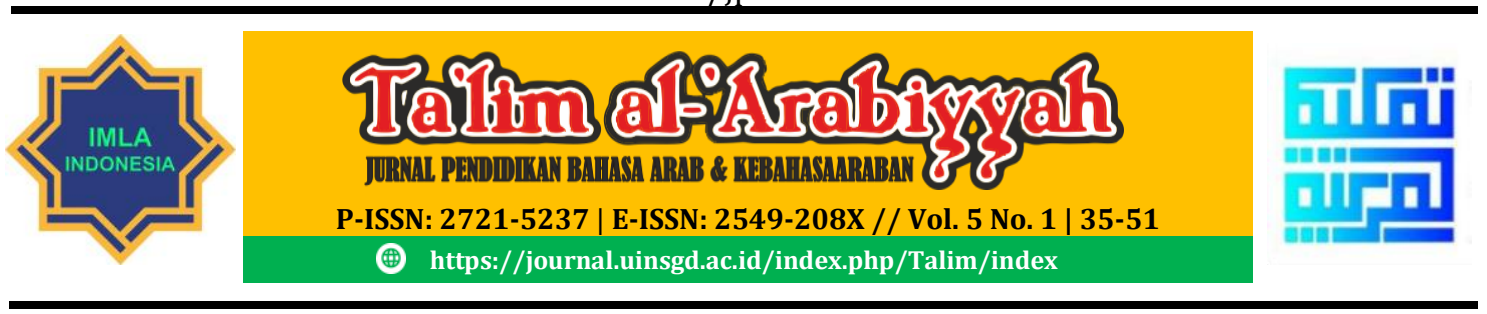

\title{
Mingle Model for Increasing Productive Language Skills and Realationship with Student's Personality based on Jung Theory
}

\author{
Suci Ramadhanti Febriani ${ }^{1}$, Wildana Wargadinata ${ }^{2}$, Syuhadak ${ }^{3}$ \\ UIN Maulana Malik Ibrabim Malang, Indonesia \\ Corresponding E-mail: suciramadhantifebriani11@gmail.com
}

\begin{abstract}
This study aims to find the effect of the implemetation of the Mingle Model on productive language skills and the relationship to the personality based on Carl Gustav Jung Theory in Arabic learning at MTsN Batu City, East Java. This research used a quantitative approach by combining the experimental and correlation methods, it was applying the Mingle Model to improve students' productive skills (speaking and writing) which have been divided into two groups; the Experiment and Control group and connected using the correlation method to extroverted and introverted students based on the theory of Carl Gustav Jung. Data collection through questionnaires, tests, and documentation. The results showed that there was a significant relationship to students' productive skills after applying the Mingle Model and there were no significant differences between extroverted and introverted students. This research recommend that the Mingle Model can be applied to improve students' productive skills. This study recommends further research to utilise more varied research methods with more diverse variables.
\end{abstract}

Keywords: Carl Gustav Jung, Extrovert, Introvert, Mingle Model, Productive Skills

\section{ABSTRAK}

Penelitian ini bertujuan untuk menemukan efektivitas implemetasi Model Mingle pada keterampilan produktif berbahasa dan hubungannya dengan kepribadian berdasarkan Teori Carl Gustav Jung dalam pembelajaran bahasa Arab di MTsN Kota Batu, Jawa Timur. Penelitian ini menggunakan pendekatan kuantitatif dengan menggabungkan metode eksperimen dan korelasi. Hal itu untuk menganalisis Model Mingle untuk meningkatkan keterampilan produktif siswa (berbicara dan menulis) yang telah dibagi menjadi dua kelompok; kelompok Eksperimen dan Kontrol dan dilanjutkan menggunakan metode korelasi untuk siswa yang ekstrovert dan introvert berdasarkan teori Carl Gustav Jung. Pengumpulan data melalui kuesioner, tes, dan dokumentasi. Hasil penelitian menunjukkan bahwa ada hubungan yang signifikan dengan keterampilan produktif siswa setelah menerapkan Model Mingle dan tidak ada perbedaan yang signifikan antara siswa ekstrovert dan introvert. Penelitian ini merekomendasikan bahwa Model Mingle dapat diterapkan untuk meningkatkan keterampilan produktif siswa. Penelitian ini merekomendasikan penelitian lanjutan untuk menggunakan metode penelitian yang lebih bervariasi dengan variabel yang lebih beragam.

Kata Kunci: Carl Gustav Jung, Extrovert, Introvert, Keterampilan Produktif, Model Mingle. 
Ta'lim al-'Arabiyyah : Jurnal Pendidikan Bahasa Arab dan Kebahasaaraban, 5 (1), 2021

\section{INTRODUCTION}

Language is the most important communication tool that humans do in order to interact with each other to convey an idea. Anca Sirbu said that language is a means of communication among community members basically (Sirbu, 2015). People have personal experiences when communicating in foreign languages (Davies, 1976). When a person starts learning a foreign language, they certain and unconsciously exposed to both categories of language skills, it's receptive and productive skills (Sadiku, 2015). Speaking and writing are one component of language productive skills but have different modes of production (Chaboki et al., 2019) The category of receptive skills is known as passive skills which consist of reading and listening skills, while productive skills are known as active skills which means the transmission of information produced by language users both in oral and written formulation (Golkova \& Hubackova, 2014).

Foreign language learners mostly begin their way of mastering a new language by observing, reading, and gathering language experience. Based on research, it is known that the person produces language through verbal in greater quantities than in writing. However, productive skills are very much needed in the interactions carried out and are still one of the controversial topics in the field of teaching foreign languages to be studied (Studies, 2014). However, there are students can't make the same improvement in speaking skills and writing skills about those who get the same help from the teacher (Samand et al., 2019).

The percentage of the use of language skills can be known from research in communication, $40-50 \%$ for listening, $25-30 \%$ for speaking, $11-16 \%$ for reading and $9 \%$ in writing (Prihartini et al., 2019). From the results of this study, it is known that the percentage in productive skills is crucial for someone in language. From the phenomenon, it is known that the more intensity a person produces language through productive skills, the problems that arise also increase.

Based on the observation at Madrasah Tsanawiyah Negeri Batu East Java that students have difficulty in producing language orally or writing. Though these students have high intelligence. This is seen when students answer on written questions. However, students are still very minimal to be able to convey ideas, answers to questions given by the teacher, causing the lack of student communication in a foreign language, it's Arabic. It is different when students produce written language, so that writing is clear and explicit, students need to arrange a number of skills, such as hand writing and spelling skills and linguistic knowledge (Leong et al., 2019). For this reason, it is necessary to have an appropriate and relevant learning model to increasing productive skills in foreign languages.

Some of the causes of students' difficulties in producing Arabic are the lack of variety of learning that teachers use when teaching, this causes the motivation of students to be minimal in learning it. This is also supported by previous research that 
the learning process undertaken by the teacher greatly determines student motivation (Mahmudi et al., 2019). The result is when the value obtained does not meet the objectives to be achieved properly.

From the perception, the productive language skills are very important, therefore, the teacher should use a learning model that is interactive, innovative and not boring, so the language production process is very enjoyable. One learning model that helps students produce foreign languages is the Mingle model (Darmayenti \& Nofiadri, 2015). The Mingle model is a new technique for teaching speaking that was developed by Darmayenti. Some scholars have investigated the relationships, contributions, and implementation of socializing techniques in the classroom. Based on a number of relevant articles, the effects of content evaluation display the limitations of research on the integrated effects of the mingle model (Rahman, 2017).

This model was initially adopted when students approached their classmates, talked for a while, and then moved to talk with other classmates using cards containing material information (Binti Jasni \& Ardiansyah, 2020). The hallmark of Mingle's activities is that all students work together, in pairs or in small groups, and move from one friend to another while talking, listening, and making detailed notes on the information they get from their friends. Face to face will form interactions, at least a few other students have one main goal to interact with each other in groups. When two people have finished a conversation, they change partners randomly or in an organized manner; for example, if they stand or sit facing each other in two circles, the pair changes when one circle moves clockwise. As for the teacher, they can't control every student involved in Mingle activities and usually the teacher focuses on students who might need special guidance. Some of the advantages obtained when using the Mingle model one of them is to pay attention to the psychological aspects of students in language when Mingle activities are carried out (Borzova, 2014).

In addition to learning innovation factors, the factors that influence a person's language are personality factors (Jialing, 2019). The relationship between personality and language skills have become interesting topics in this decade (Sharp, 2009). Based on the initial analysis that when someone is quiet, then they will put forward a little communication, in contrast to someone who has a fussy personality background, they will more in producing language. On that basis, the need for teachers to understand the psychological side of students in guiding students to communicate verbally and in writing(Febriani \& Anasruddin, 2020).

Personality comes from the word "personality", which means mask. The mask was always worn by people who played the role of the Romans and Greeks. The word persona comes from Romanian and has similarities with the Greek word Prasapon. Experts reveal that the word persona comes from the Latin word per-sonare, which means mask.(Alwisol, 2012) Based on Carl Gustav Jung's theory which states that 
personality is generally divided into two types, it's Extrovert and Introvert personality (Boeree, n.d.).

According to Carl Gustav Jung, Extrovert personalities tend to appear far more social because they are eager to stimulate something new when meeting new people. They also tend to think and talk at the same time, and formulate it in the best idea by saying it out loud. Whereas Introverts have a profound ability of insight when they are given time and space to think things through. Throughout the world, introverts may look shy or anti-social, but they only have social relations in different ways. Introverts prefer to spend smaller group time and usually like getting it to get to know new people more slowly (Prakash et al., 2016). From the two personalities expressed, the teacher's challenge in training students to improve productive language skills is enormous. This happens when the two personalities have different contradictions, and have an impact on the learning outcomes of Arabic in the classroom.

Cath Mogan also stated in his research that innovative learning collaboration will provide access to thoughts, experiences, solutions, knowledge and skills that will become an integral factor in learning a foreign language (Hogan, n.d.). Based on research by Nudzejma Obralic and others, that a student's personality can influence overall success in learning a foreign language. In addition, other studies showen that extraversion-introversion has a significant relationship with different language learning skills, the finding is that students who score high on extraversion tend to score better in speaking and reading skills, while introverts tend to perform better in skills listening while writing skills do not correlate strongly with any of the personality traits (Zafar et al., 2017).

Based on the information before, it is known that language learning strategies can also have an impact on the mastery of foreign languages (Obralic \& Mulalic, 2017). Therefore, foreign language learning is interconnected with language acquisition while learning in the classroom (Emily \& Mclaughlin, 2014). Although the two are not closely related; motivational factors (Karim et al., 2016), personality and teacher considerations in choosing strategies, methods or models of learning in foreign language classes, this can significantly help students in learning foreign languages. For this reason, the purpose of this study is to determine the effectiveness of Mingle learning models for productive language skills; speaking and writing skills. This research aims to answer the following questions: 1) How is the learning process using the Mingle Model in increasing productive ability in Arabic in Extrovert and Introvert students?; 2) What is the effectiveness of the Mingle learning model on the productive ability of speaking (speaking and writing) Extrovert and Introvert students?; 3) How is the relationship between the personality of the Esktrovert and Introvert students to the speaking skills; 4) How is the relationship between the Extrovert and Introvert students' to the writing skills?. 


\section{METHOD}

This study used a quantitative approach using experimental methods to determine the effectiveness of learning productive skills of students with extroverted and introverted personalities, after that researchers used the correlation method to analyze the relationship between extroverted and introverted students with productive skills after using the Mingle model in Arabic learning.

The study population 267 students in MTsN Batu by taking a rundown sample of 30 students for correlation research. The following is the sample exposure used:

Table 1. Sample of research

\begin{tabular}{|c|c|c|}
\hline Personality $(\mathrm{B})$ & \multicolumn{2}{|c|}{ Mingle Model $(\mathrm{A})$} \\
\hline & Speaking Skills $\left(\mathrm{A}_{1}\right)$ & Writing Skills $\left(\mathrm{A}_{2}\right)$ \\
\hline Ekstrovert $\left(\mathrm{B}_{1}\right)$ & $\mathrm{A}_{1} \mathrm{~B}_{1}$ & $\mathrm{~A}_{2} \mathrm{~B}_{1}$ \\
\hline Introvert $\left(\mathrm{B}_{2}\right)$ & $\mathrm{A}_{1} \mathrm{~B}_{2}$ & $\mathrm{~A}_{2} \mathrm{~B}_{2}$ \\
\hline
\end{tabular}

The sampling technique used rundown technique, this technique takes research samples randomly conducted as follows: 1) researchers divided the questionnaire to class IX students consisting of 42 questions that will classify students based on Carl Gustav Jung's theory that divides students into two groups based on their personality, it's students with extrovert and introvert personality; 2) After the distributes questionnaires in class IX, the researchers only need to take as many as 30 extroverted students and 30 introverted students; 3 ) divided the class for extroverted and introverted students with 15 student's for the experimental group and 15 students for the control group, then the researchers conducts a pre-test to find out the students 'productive skills; speaking and writing skills; 4) apply the Mingle learning model in three meetings by teaching material based on teaching materials applied at school, 5) looks at the results of the post-test of experimental and control students for each extrovert and introvert students 6) analyze the score obtained.

In using the test, the researcher used an oral test to find out the students' speaking skills one by one in interview techniques on extroverted and introverted students, while the researchers used written tests for writing skills in the form of descriptive questions. This test was validated by experts before verbal and written questions were distributed. After applying the Mingle model, the researchers calculated the learning effectiveness of the Mingle model using t-Test and correlated it with extroverted and introverted personalities using moment product analysis techniques with of SPSS 16.00 , the accuracy rate is $95 \%$.

\section{RESULT AND DISCUSSION}

Based on the student classification questionnaire with 42 items, it aimed at dividing students into their personality tendencies, which are classified as extroverted or introverted personalities, the researchers found 60 students divided into two groups; 30 extroverted students and 30 introverted students, then researchers divided into two different classes; one class consisting of 30 extroverted children, the 
researcher divided the two groups; the experimental group and the control group, as well as the class of students with introvert personality. The following classification of students based on questionnaire calculation.

Table 2. Classification of personality

\begin{tabular}{|l|c|c|c|c|}
\hline Personality & \multicolumn{2}{|c|}{$\begin{array}{c}\text { Class (A) } \\
\text { Experiment Class } \\
\text { (30 students) }\end{array}$} & \multicolumn{2}{c|}{$\begin{array}{c}\text { Class (B) } \\
\text { Control Class } \\
\text { (30 students) }\end{array}$} \\
\hline Ekstrovert & 15 & 15 & 15 & 15 \\
\hline Introvert & 15 & 15 & 15 & 15 \\
\hline
\end{tabular}

After classification the students, data is obtained, the researchers conducted a pre-test of the productive skills of Arabic speaking students; speaking and writing skills in the control and experimental class. After that, researchers applied the Mingle model which was carried out as follows:

The Arabic Learning Activities using the Mingle Model are divided into three main activities. Before the presentation of these activities, the teacher should prepare a learning plan and see the core competencies and basic competencies that will be guided as indicators of achievement and learning objectives. After that, Mingle activities are divided into three main parts, it's: 1 ) Introduction activities consisting of; The teacher makes apperception by praying, checking the attendance of students and asking some questions related to the material being played. 2) The core activities are divided into five aspects which are adopted from the scientific approach as follows.

Observe; The teacher prepares colorful cards containing information and pictures, the teacher prepares a gift; Ask; The teacher informs the topic and students are given the opportunity to ask questions about the topic, the teacher explains the activities to be carried out; Explore / gather information, the teacher gives examples of pronunciation of phrases and is followed by students, the teacher asks one student to imitate one simple phrase, the designated student is asked to ask another friend in turn, all students have the opportunity to talk alternately.

Association / reasoning / information processing; Define the rules of the game, the teacher conveys the rules of the game, the teacher divides students into groups, the teacher gives the card to students and gives a few minutes to understand the information on the card, the teacher gives examples of expressions that will be done by students, the teacher asks students to appear in groups, the teacher asks students stand up, move and move while having conversations based on information on the card, the teacher monitors student activities, the teacher provides an opportunity for the winning group to present in front of the class and give prizes.

Confirmation: The teacher and students discuss the topics carried out, the teacher provides reinforcement and feedback on the topics discussed, the teacher and students conclude the topics that have been discussed. After the process of core 
activities, the closing activities carried out in this Mingle model are the teacher carrying out oral assessments, the teacher close the lesson and pray and greet.

\section{Figure 1. Mingle Model}

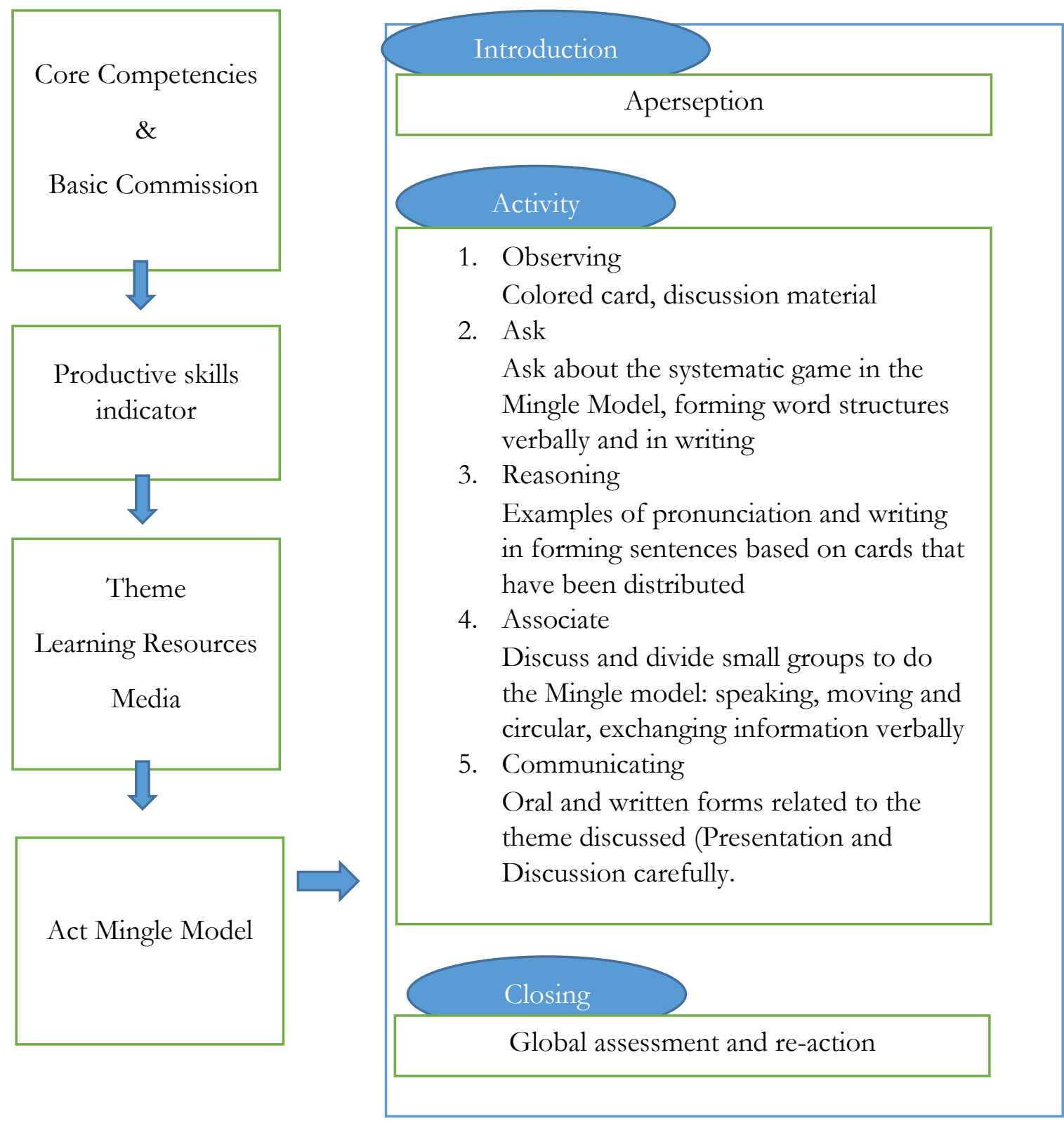

After the implementation of the Mingle learning model was implemented as in Figure 1, the researchers looked at the effectiveness of this model with the student's post test. The results obtained can be seen as follows:

Table 3. Personality scores of Extroverted students on speaking skills 
Ta'lim al-'Arabiyyah : Jurnal Pendidikan Bahasa Arab dan Kebahasaaraban, 5 (1), 2021

\begin{tabular}{|c|c|c|c|c|c|}
\hline & & Frequency & Percent & Valid Percent & $\begin{array}{c}\text { Cumulative } \\
\text { Percent }\end{array}$ \\
\hline \multirow[t]{18}{*}{ Valid } & 64 & 1 & 2.8 & 3.3 & 3.3 \\
\hline & 74 & 1 & 2.8 & 3.3 & 6.7 \\
\hline & 77 & 2 & 5.6 & 6.7 & 13.3 \\
\hline & 78 & 2 & 5.6 & 6.7 & 20.0 \\
\hline & 80 & 1 & 2.8 & 3.3 & 23.3 \\
\hline & 81 & 2 & 5.6 & 6.7 & 30.0 \\
\hline & 83 & 2 & 5.6 & 6.7 & 36.7 \\
\hline & 84 & 2 & 5.6 & 6.7 & 43.3 \\
\hline & 86 & 2 & 5.6 & 6.7 & 50.0 \\
\hline & 87 & 2 & 5.6 & 6.7 & 56.7 \\
\hline & 88 & 2 & 5.6 & 6.7 & 63.3 \\
\hline & 89 & 2 & 5.6 & 6.7 & 70.0 \\
\hline & 90 & 1 & 2.8 & 3.3 & 73.3 \\
\hline & 91 & 4 & 11.1 & 13.3 & 86.7 \\
\hline & 92 & 2 & 5.6 & 6.7 & 93.3 \\
\hline & 93 & 1 & 2.8 & 3.3 & 96.7 \\
\hline & 94 & 1 & 2.8 & 3.3 & 100.0 \\
\hline & Total & 30 & 83.3 & 100.0 & \\
\hline Missing & System & 6 & 16.7 & & \\
\hline Tot & & 36 & 100.0 & & \\
\hline
\end{tabular}

Table 4. Personality scores of Extroverted students on writing skills

\begin{tabular}{|cc|c|c|c|c|}
\hline & & Frequency & Percent & Valid Percent & $\begin{array}{c}\text { Cumulative } \\
\text { Percent }\end{array}$ \\
\hline Valid & $\mathbf{6 3}$ & $\mathbf{2}$ & 5.6 & 6.7 & 6.7 \\
& $\mathbf{6 7}$ & $\mathbf{1}$ & 2.8 & 3.3 & 10.0 \\
& $\mathbf{7 5}$ & $\mathbf{4}$ & 11.1 & 13.3 & 23.3 \\
$\mathbf{7 6}$ & $\mathbf{1}$ & 2.8 & 3.3 & 26.7 \\
$\mathbf{7 7}$ & $\mathbf{2}$ & 5.6 & 6.7 & 33.3 \\
$\mathbf{7 9}$ & $\mathbf{3}$ & 8.3 & 10.0 & 43.3 \\
$\mathbf{8 0}$ & $\mathbf{3}$ & 8.3 & 10.0 & 53.3 \\
$\mathbf{8 1}$ & $\mathbf{3}$ & 8.3 & 10.0 & 63.3 \\
\hline
\end{tabular}


Ta'Cim al-'Arabiyyah : Jurnal Pendidikan Bahasa Arab dan Kebahasaaraban, 5 (1), 2021

\begin{tabular}{|c|c|c|c|c|}
\hline $\mathbf{8 2}$ & $\mathbf{3}$ & 8.3 & 10.0 & 73.3 \\
$\mathbf{8 3}$ & $\mathbf{2}$ & 5.6 & 6.7 & 80.0 \\
$\mathbf{8 4}$ & $\mathbf{1}$ & 2.8 & 3.3 & 83.3 \\
$\mathbf{8 5}$ & $\mathbf{1}$ & 2.8 & 3.3 & 86.7 \\
$\mathbf{8 7}$ & $\mathbf{1}$ & 2.8 & 3.3 & 90.0 \\
$\mathbf{8 9}$ & $\mathbf{1}$ & 2.8 & 3.3 & 93.3 \\
$\mathbf{9 4}$ & $\mathbf{2}$ & 5.6 & 6.7 & 100.0 \\
Total & $\mathbf{3 0}$ & 83.3 & 100.0 & \\
Missing System & $\mathbf{6}$ & 16.7 & & \\
Total & 36 & 100.0 & & \\
\hline
\end{tabular}

Table 5. Personality scores of Introverted students on speaking skills

\begin{tabular}{|cc|c|c|c|c|}
\hline & & Frequency & Percent & Valid Percent & $\begin{array}{c}\text { Cumulative } \\
\text { Percent }\end{array}$ \\
\hline Valid & $\mathbf{6 2}$ & $\mathbf{1}$ & 3.3 & 3.3 & 3.3 \\
& $\mathbf{6 7}$ & $\mathbf{1}$ & 3.3 & 3.3 & 6.7 \\
& $\mathbf{6 9}$ & $\mathbf{1}$ & 3.3 & 3.3 & 10.0 \\
$\mathbf{7 0}$ & $\mathbf{1}$ & 3.3 & 3.3 & 13.3 \\
$\mathbf{7 1}$ & $\mathbf{3}$ & 10.0 & 10.0 & 23.3 \\
$\mathbf{7 4}$ & $\mathbf{4}$ & 13.3 & 13.3 & 36.7 \\
$\mathbf{7 7}$ & $\mathbf{2}$ & 6.7 & 6.7 & 43.3 \\
$\mathbf{7 8}$ & $\mathbf{2}$ & 6.7 & 6.7 & 50.0 \\
$\mathbf{8 0}$ & $\mathbf{1}$ & 3.3 & 3.3 & 53.3 \\
$\mathbf{8 1}$ & $\mathbf{3}$ & 10.0 & 10.0 & 63.3 \\
$\mathbf{8 2}$ & $\mathbf{3}$ & 10.0 & 10.0 & 73.3 \\
$\mathbf{8 6}$ & $\mathbf{2}$ & 6.7 & 6.7 & 80.0 \\
$\mathbf{8 7}$ & $\mathbf{2}$ & 6.7 & 6.7 & 86.7 \\
$\mathbf{8 8}$ & $\mathbf{1}$ & 3.3 & 3.3 & 90.0 \\
$\mathbf{8 9}$ & $\mathbf{2}$ & 6.7 & 6.7 & 96.7 \\
$\mathbf{9 0}$ & $\mathbf{1}$ & 3.3 & 3.3 & 100.0 \\
Total & 30 & 100.0 & 100.0 & \\
\hline
\end{tabular}


Ta'lim al-'Arabiyyah : Jurnal Pendidikan Bahasa Arab dan Kebahasaaraban, 5 (1), 2021

Tabel 6. Personality scores of Introverted students on writing skills

\begin{tabular}{|cc|c|c|c|c|}
\hline & & Frequency & Percent & Valid Percent & $\begin{array}{c}\text { Cumulative } \\
\text { Percent }\end{array}$ \\
\hline Valid & $\mathbf{6 8}$ & $\mathbf{3}$ & 10.0 & 10.0 & 10.0 \\
& $\mathbf{7 2}$ & $\mathbf{2}$ & 6.7 & 6.7 & 16.7 \\
& $\mathbf{7 4}$ & $\mathbf{4}$ & 13.3 & 13.3 & 30.0 \\
$\mathbf{7 5}$ & $\mathbf{1}$ & 3.3 & 3.3 & 33.3 \\
$\mathbf{7 7}$ & $\mathbf{1}$ & 3.3 & 3.3 & 36.7 \\
$\mathbf{7 9}$ & $\mathbf{1}$ & 3.3 & 3.3 & 40.0 \\
$\mathbf{8 0}$ & $\mathbf{3}$ & 10.0 & 10.0 & 50.0 \\
$\mathbf{8 1}$ & $\mathbf{1}$ & 3.3 & 3.3 & 53.3 \\
$\mathbf{8 2}$ & $\mathbf{4}$ & 13.3 & 13.3 & 66.7 \\
$\mathbf{8 4}$ & $\mathbf{3}$ & 10.0 & 10.0 & 76.7 \\
$\mathbf{8 8}$ & $\mathbf{3}$ & 10.0 & 10.0 & 86.7 \\
$\mathbf{8 9}$ & $\mathbf{1}$ & 3.3 & 3.3 & 90.0 \\
$\mathbf{9 1}$ & $\mathbf{1}$ & 3.3 & 3.3 & 93.3 \\
$\mathbf{9 2}$ & $\mathbf{1}$ & 3.3 & 3.3 & 96.7 \\
$\mathbf{9 5}$ & $\mathbf{1}$ & 3.3 & 3.3 & 100.0 \\
Total & 30 & & 100.0 & 100.0 & \\
\hline
\end{tabular}

Based on the learning outcomes using the Mingle Model, the significance test obtained by the SPSS program is as follows:

Based on the output table before in the Equal variances assumed section, it is known that 92 -tailed gignification) is $0.22<0.05$, so the decision is made that $\mathrm{H}_{\mathrm{o}}$ is rejected, $\mathrm{H}_{\mathrm{a}}$ is accepted. As for based on $\mathrm{t}$ arithmetic, that the value of $\mathrm{t}$ count $>\mathrm{t}$ table, then $\mathrm{H}_{\mathrm{a}}$ is accepted, i.e. $(4,702>2.00)$.

With the calculation, it means that there are differences in the average student learning score between the control and experimental groups after applying the Mingle learning model to the process of improving language productive skills.

\section{Relationship between Student Personality and Productive Language Skills}

The relationship between students' personality and productive language skills can be measured after the researcher distributes questionnaires for the classification of extroverted and introverted students. Each group consisted of 30 people and was 
Ta'Cim al-'Arabiyyah : Jurnal Pendidikan Bahasa Arab dan Kebahasaaraban, 5 (1), 2021

divided into control and experiment groups. Following are the results of data analysis calculations using SPSS with moment product analysis. The following calculation results can be seen from the table below which is divided into four parts;

Table 7. Relationship of Extrovert personality with speaking skills

\begin{tabular}{|r|l|l|}
\hline & EKSTROVERT & Speaking \\
\hline EKSTROVERT Pearson Correlation & 1 & .196 \\
Sig. (2-tailed) & & .300 \\
$\mathrm{~N}$ & 30 & 30 \\
\hline Speaking Pearson Correlation & .196 & 1 \\
Sig. (2-tailed) & .300 & \\
$\mathrm{~N}$ & 30 & 30 \\
\hline
\end{tabular}

Tabel 8. Relationship of Extrovert personality with writing skills

\begin{tabular}{|r|l|l|}
\hline & EKSTROVERT & Writing \\
\hline EKSTROVERT Pearson Correlation & 1 & -.011 \\
Sig. (2-tailed) & & .952 \\
$\mathrm{~N}$ & 30 & 30 \\
\hline Writing Pearson Correlation & -.011 & 1 \\
Sig. (2-tailed) & .952 & \\
$\mathrm{~N}$ & 30 & 30 \\
\hline
\end{tabular}

Tabel 9. Relationship of Introvert personality with speaking skills

\begin{tabular}{|r|l|l|}
\hline & INTROVERT & Speaking \\
\hline INTROVERT Pearson Correlation & 1 & -.023 \\
Sig. (2-tailed) & & .903 \\
$\mathrm{~N}$ & 30 & 30 \\
\hline Speaking Pearson Correlation & -.023 & 1 \\
Sig. (2-tailed) & .903 & \\
$\mathrm{~N}$ & 30 & 30 \\
\hline
\end{tabular}

Tabel 10. Relationship of Introvert personality with writing skills

\begin{tabular}{|r|l|l|}
\hline & INTROVERT & Writing \\
\hline INTROVERT Pearson Correlation & 1 & .035 \\
Sig. (2-tailed) & & .855
\end{tabular}




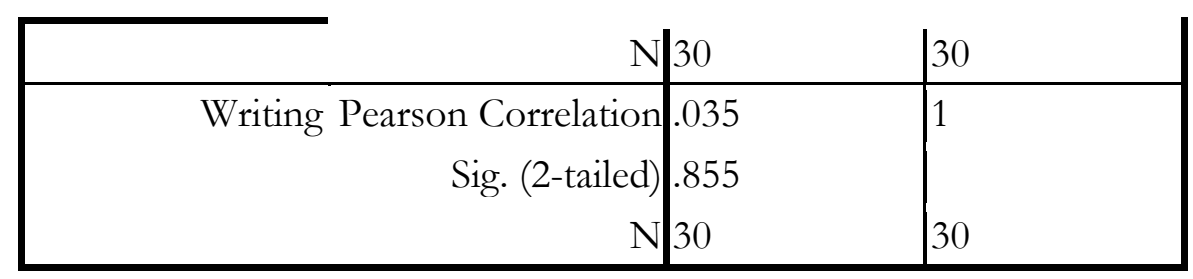

From the calculation of product moment to measure the relationship between Extrovert and Introvert personality towards productive ability, it is seen that extroverted personality towards speaking skills has a significance value of 0.196 . The relationship of extroverted personality to writing skills gained a significance value of 0.11 . While the introvert personality relationship with speaking skills gained a score of -0.23 . While the significance value of the introvert personality relationship to writing skills was 0.35 .

Based on the $r$ table value for the total sample of 30 people, the $r$ table value is 0.361 . Then, it is seen that the hypothesis for these four variables is $\mathrm{H}_{\mathrm{o}}$ accepted. Because $r$ count is smaller than $r$ table, i.e. $(0.196<0.361),(-0.11<0.361),(-0.23$ $<0.361)$, $(0.35<0.361)$.

This calculation used an accuracy rate of $95 \%$. So, it can be concluded that the personality of Extrovert or Introvert students does not have a significant relationship, while the Mingle Model influences students' productive skills, the ability to speaking and writing. For this reason, the learning process using the Mingle model is very relevant to the learning of productive language skills.

\section{Findings}

The results showed that the process of teaching productive skills speaking and writing in MTsN Batu does not yet have detailed learning objectives. So that researchers design in detail. Most Arabic teachers do not encourage students to speak and write intensely. Most students remain silent during the teaching process. They tend to read rather than produce language. The teacher used to explain the material to students. In addition, Arabic language teachers at MTsN Batu tend to use traditional seating rows.

This is different from Mingle learning which pays attention to students psychologically in language foreign learning, because students have the same opportunity to get teacher guidance, the arrangement of chairs is formed in a circle so that it makes it easy for students to make small circles, move in a clockwise direction to talk and pay attention to the answers of their friends. Seating arrangements in the teaching process with the Mingle model are made to make students more active and more enjoyable. In accordance with Davis's (2018) statement in his research that in designing effective learning requires good classroom management 
Based on the results of the research before that the teaching process is not enough just to describe student skills in speaking and writing. The teaching process carried out by the teacher in learning used the Mingle model which consists of four steps, namely preparation, pre-activity, main activities and post-activities. However, these steps have not yet reached the goal of teaching the desired speaking and writing skills. When teachers apply the Mingle Model, teachers must pay attention to core competencies, basic competencies, indicators of student progress, and teaching objectives, teaching materials at the Middle School level, and evaluations that will be conducted.

In the Mingle model, there are pre, main, and post activities. Pre-activity includes preparation. The main activities include orientation, exploration, interpretation, re-creation or confirmation, posting activities including conclusions and reflections. The results of developing the Mingle model include preparation; warming up; set rules; acting Mingle model; presentation; review and discussion. As the statement states that the learning planning to the evaluation process needs to be designed as well as possible, with it the teacher easily carry out the stages of learning Arabic in accordance with the learning plan (Baharuddin, 2017).

Basically, the learning process that pays attention to the psychological side of students will have an impact on good learning outcomes, because learning a foreign language is a long process and complex (Mirhadizadeh, 2016). This is accordance with Hunchinson's statement in Nazanin which revealed that language learning is an emotional experience (Dewaele, 2019) and the feeling that the learning process arouses will have an important influence on success or failure in learning. The result is emotional feelings will affect student motivation (Aguilar, 2013). In addition, the teacher's role is crucial in determining learning outcomes along with research from Hongzhi (Yang, 2019). Thus, with the Mingle learning model, Arabic production skills are very easy to improve. Related to this, the Mingle Model is very concerned about the psychological side of students, where the level of students at the elementary school and junior high school is still in the learning phase while playing. Therefore, psychological factors and the process of active and collaborative learning are very important in applying the Mingle model.

Related to the relationship between the extrovert and introvert personality towards language skills, there is no significant relationship between extroverted and introverted personalities on productive language skills. This is different results from the findings of Maria Ulfa who suggested a significant relationship between the two (Darmayenti \& Nofiadri, 2015). Researchers compare that other determinants are environmental factors that play a role. In this study, samples were taken from students of MTsN Batu who did not have an adequate language environment as a medium to improve students' productive language skills. Whereas in previous studies, Maria Ulfa used a sample of students who lived in Islamic boarding schools who had environmental facilities in communicating foreign languages. Meanwhile Siswoto said 
that introverted students had higher speaking skills than extroverted students (Prayitno \& Ayu, 2018). To that end, the new findings in this study illustrate that productive foreign language skills are higher in verbal students with extroverted personality than introverts. Other findings show that students with introverted personality scores are higher than extroverted students in terms of their writing skills.

Various factors greatly affect productive language skills. According to research findings that several factors that influence are intelligence, motivation, perception, personality, and environment (Mirhadizadeh, 2016). Based on the findings in this study indicated that personality factors do not have a significant influence on productive skills. By the assumption that there are other factors that have a greater effect on one's language skills compared to personality factors. Analogically, the environment is one of the main reasons that can affect productive language skills. After the researchers conducted in-depth observations and interviews that MTsN Batu did not have a speaking environment. This is very determining and influences the overall student skills.

\section{CONCLUSION}

Based on the results of data analysis, it is known that the Mingle model is suitable for students to improve learning outcomes in terms of productive Arabic language skills. With this fact, the teacher should be able to design innovative, creative, fun learning and practice critical thinking that is tailored to the student's personality. This study shows that the results of applying the Mingle model are very significant for students' productive skills. The difference between Extroverted students' scores was higher in speaking skills, while other findings showed that Introverted students had higher grades in writing skills. A psychologinguistic approach that is known to the teacher so that they are able to deal with students with extrovert and introvert personality that will have an impact on maximum results in learning activity. Educational success is not only determined by external factors, but the ability of teachers in designing learning really encourages students to increase their capacity to be creative, collaborate and communicate well, because learning is a very complex step, therefore it is advisable for teachers to consider factors which influences the learning process. They need to be aware of all the factors within each individual by considering all the differences students have and the influence of other external factors. 
Ta'lim al-'Arabiyyah : Jurnal Pendidikan Bahasa Arab dan Kebahasaaraban, 5 (1), 2021

\section{REFERENCES}

Aguilar, A. P. (2013). Emotions as Learning Enhancers of Foreign Language Learning Motivation. Profile Issues in Teachers' Professional Development, 15(1), 109-124.

Alwisol. (2012). Psikologi Kepribadian. UMM Press.

Baharuddin. (2017). Psikologi Pendidikan. Arruz Media.

Binti Jasni, N. S., \& Ardiansyah, A. A. (2020). Arabic Learning Based On E-Learning Using Arabic Teacher Website In The Pandemic Era Of Covid-19. Ta'lim Al'Arabiyyah: Jurnal Pendidikan Bahasa Arab \& Kebahasaaraban, 4(2), 122-137. https://doi.org/10.15575/jpba.v4i2.8601

Borzova, E. (2014). Mingles in the Foreign Language Classroom.

C. George Boeree. (n.d.). Personality Theories. Psychology Department Shippensburg University.

Chaboki, S., Heidar, M., Journal, I., Education, E., \& Published, O. A. (2019). Farzaneh Safari Chaboki 1 \&o Davood Mashbadi Heidar 1*. May, 61-72.

Darmayenti, D., \& Nofiadri, N. (2015). Mingle Model for Teaching English Speaking Skill for College Students. AL-Ta Lim, 22(1), 1.

https://doi.org/10.15548/jt.v22i1.115

Davies, N. F. (1976). Receptive Versus Productive Skills in Foreign Language

Learning. The Modern Language Journal, 60(8), 440-443.

https://doi.org/10.1111/j.1540-4781.1976.tb03667.x

Dewaele, J. M. (2019). Multilingualism and trait emotional intelligence: an exploratory investigation. International Journal of Multilingualism, $0(0), 1-15$.

https://doi.org/10.1080/14790718.2019.1571065

Emily, P., \& Mclaughlin, T. F. (2014). International Journal of English and Education. International Journal of English and Education, 3(2), 581-584.

Febriani, S. R., \& Anasruddin, A. (2020). Technology for Four Skills Arabic in the Era Emergency of Covid-19 in Indonesia. Ta'lim Al-'Arabiyyah: Jurnal Pendidikan Bahasa Arab \& Kebahasaaraban, 4(1), 1-11. https://doi.org/10.15575/jpba.v4i1.8221

Golkova, D., \& Hubackova, S. (2014). Productive Skills in Second Language Learning. Procedia - Social and Behavioral Sciences, 143, 477-481. https://doi.org/10.1016/j.sbspro.2014.07.520

Hogan, C. (n.d.). Productive Collaboration Through Teaching Of Personality Cath Hogan The Hutchins School, Tasmania, Australia.

Karim, N. A., Nur, S., \& Mohd, D. (2016). Personality factors and second language acquisition: An islamic viewpoint. International Journal of Business, Economics and Law, 11(5), 12-19. 
Ta'lim al-'Arabiyyah : Jurnal Pendidikan Bahasa Arab dan Kebahasaaraban, 5 (1), 2021

Leong, C. K., Shum, M. S. K., Tai, C. P., Ki, W. W., \& Zhang, D. (2019). Differential contribution of psycholinguistic and cognitive skills to written composition in Chinese as a second language. Reading and Writing, 32(2), 439-466. https://doi.org/10.1007/s11145-018-9873-2

Mahmudi, A., Febriani, S. R., Hasanah, M., Arifa, Z., Islam, U., Maulana, N., Ibrahim, M., Malang, K., \& Timur, J. (2019). Classroom Management And Arabic Learning Process Based On Multiple Arabiyât. 6(2), 222-237.

Mirhadizadeh, N. (2016). Internal and external factors in language change. Internal and External Factors in Language Learning, 1(5), 188-196.

Obralic, N., \& Mulalic, A. (2017). Correlation between Personality Traits and Language Learning Strategies among IUS Students. Journal of Applied Linguistics and Language Research, 4(5), 76-84.

Prakash, S., Singh, A., \& Yadav, S. K. (2016). Personality (Introvert, And Extrovert) and Professional Commitment Effect among B . Ed Teacher Educator Students. The International Journal of Indian Psychology, 3(2).

Prayitno, S. H., \& Ayu, S. M. (2018). Hubungan Antara Kepribadian Introvert Dan Ekstrovert Dengan Speaking Skill Mahasiswa Prodi D III Keperawatan Tahun Akademik 2017/2018. Insight: Jurnal Pemikiran Dan Penelitian Psikologi, 14(1), 60. https://doi.org/10.32528/ins.v14i1.1077

Prihartini, Y., Buska, W., \& Hasnah, N. (2019). Analysis of Test Item on the Final Test Semester Exam on Arabic Subjects. Arabiyat: Jumal Pendidikan Bahasa Arab Dan Kebahasaaraban, 6(1), 71-92. https://doi.org/10.15408/a.v6i1.10926

Rahman, M. A. (2017). LET: Linguistics, Literature and English Teaching Journal A Review Of The Mingle Model As A New Technique In Teacbing Speaking: Indonesian Context. 7(2), 181-194.

Sadiku, L. M. (2015). The Importance of Four Skills Reading, Speaking, Writing, Listening in a Lesson Hour. European Journal of Language and Literature, 1(1), 29. https://doi.org/10.26417/ejls.v1i1.p29-31

Samand, S. M., Sailan, Z., \& Lio, A. (2019). Analysis On The Relationship Of Extrovert-Introvert Personality And Students' Speaking Performance In English Study Program Of Halu Oleo University. Journal of Language Education and Educational Technology (LLEET), 4(1). https://doi.org/10.33772/jleet.v4i1.6677

Sharp, A. (2009). Personality and Second Language Learning. Asian Social Science, 4(11), 17-25. https://doi.org/10.5539/ass.v4n11p17

Sirbu, A. (2015). Significance of Language as a Tool of Communication. Naval Academy Scientific Bulletin, XVIII(2), 405-406.

https://doi.org/10.1080/08039480260242741

Studies, L. (2014). Journal Of Language And Linguistic Studies Foreign language learners 'views 
Ta'Cim al-'Arabiyyah : Jurnal Pendidikan Bahasa Arab dan Kebahasaaraban, 5 (1), 2021

on the importance of learning the target language pronunciation. 10(1), 99-110.

WANG Jialing. (2019). The Relationship Between Learners' Personality Traits and EFL Learning. Sino-US English Teaching, 16(4), 135-142. https://doi.org/10.17265/1539-8072/2019.04.001

Yang, H. (2019). The nexus between pre-service teachers' emotional experience and cognition during professional experience. Australian Educational Researcher, 46(5), 799-825. https://doi.org/10.1007/s13384-019-00320-8

Zafar, S., Khan, Z. A., \& Meenakshi, K. (2017). Extraversion-introversion tendencies and their relationship with ESL proficiency: A study of Chinese students in Vellore, India. Pertanika Journal of Social Sciences and Humanities, 25(2), 687-703. 